\title{
Gaya Hidup Digital Kristiani Era Globalisasi
}

\author{
Ang Wie Hay ${ }^{1}$
}

\section{Gaya Hidup Digital}

1 erkembangan teknologi informasi dan komunikasi beserta dampaknya menjadi topik hangat di zaman postmodern ini. Keterbatasan media informasi konvensional seperti koran, radio, televisi membuat orang beralih menggunakan media informasi dunia maya yang ada di internet sebagai konsumsi kebutuhan informasi yang cepat, mutahir dan terkini. Dunia sedang terus menuju kematangan teknologi informasi dan komunikasi, bahwa segala urusan kehidupan manusia sedang menuju digitalisasi dengan segala perangkat pintar digital seperti telepon pintar, televisi pintar, kamera pintar, jam tangan pintar, mobil pin$\operatorname{tar}$ dan sebagainya serba pintar. Bersamaan dengan pesatnya kemajuan hardware, ahli-ahli teknologi informasi masih terus berusaha membuat aplikasi atau software sekali click untuk memudahkan segala urusan hidup manusia postmodern, mulai dari urusan rumah tangga, komunikasi, pendidikan, kesehatan, bisnis, hiburan, keuangan, transportasi, bahkan keagamaan.
Gaya hidup manusia postmodern ditandai dengan gaya hidup digital yaitu gaya hidup yang selalu mengandalkan dan bergantung pada perangkat pintar digital untuk kegiatan sehari hari misalnya belanja online, membaca koran atau buku digital, menonton film, transaksi keuangan digital, atau media komunikasi digital. Manusia semakin membutuhkan dan sulit dilepaskan dari alat-alat digital serba pintar. Telepon pintar, super komputer, internet, wifi, dan charger terbaru menjadi barang yang dicari-cari manusia postmodern.

Gaya hidup digital memungkinkan semua urusan aktivitas sehari-hari dengan mudah diintegrasikan di dalam satu alat pintar digital, mulai dari mengintegrasi nomor telepon rekan, email, data kesehatan, data keuangan, dan data privasi lainnya dengan mudah direkam dan diolah datanya di dalam gadget kita untuk memudahkan layanan sekali click. Saat ini adalah masa transisi dari berkurangnya penggunaan kertas menuju penggunaan sarana digital layar sentuh, contoh: Alkitab digital, tiket digital, uang digital, email, koran digital, buku digital. Perlahan na-

1. Alumnus dari Osaka Prefecture University dan dari Kobe Lutheran Theological Seminary, Japan. Saat ini melayani sebagai pengkhotbah dan pembicara seminar. 
mun pasti, dunia sedang menuju digitalisasi dari dunia nyata menjadi dunia maya digital serba pintar, interaktif, real time, terkoneksi mengglobal, lebih praktis, lebih mudah, lebih cepat dan lebih murah.

\section{Digitalisasi Menuju Globalisasi}

Dampak digitalisasi adalah keterbukaan dan penyebaran informasi di segala bidang. Generasi digital ata u iGeneration semakin mudah mendapatkan informasi secara cepat, akurat, dan transparan dari berbagai sumber di seluruh dunia melalui internet. Dinamika kehidupan yang terjadi di seluruh dunia dengan mudah diakses dan menjadi tontonan bagi iGeneration. Fenomena keterbukaan dan penyebaran informasi mengakibatkan terjadinya kondisi saling memengaruhi atau pertukaran antar kebudayaan, gaya hidup, kepercayaan, ekonomi, politik, pendidikan, gagasan/ide dan lain-lain di seluruh dunia yang disebut globalisasi di segala bidang kehidupan.

Semua standar kehidupan akan ditarik mengikuti standar global atau internasional, mulai dari standar kualitas produk barang, jasa bahkan gaya hidup. Globalisasi informasi menimbulkan persaingan global, pemuda Kristen pun dituntut untuk mampu bersaing di segala bidang dengan sangat ketat. Kualitas menjadi isu penting dalam persaingan global. Globalisasi akan semakin mendukung sistem meritokrasi, bahwa penempatan tenaga kerja berdasarkan pada prestasi dan spesialisasi yang dimiliki seseorang. Digitalisasi telah mengubah gaya hidup dan cara berpikir pemuda dari lokal menuju digital global. Kombinasi digitalisasi, globalisasi dan meritokrasi mengakibatkan pemuda dituntut untuk memacu meningkatkan kualitas diri dan mempunyai daya saing internasional.

\section{Jebakan Teknologi pada Kaum Muda}

Lambat atau cepat namun dipastikan bahwa pemuda Kristen akan mengkonsumsi informasi dari dunia maya digital. Keberagaman dan banyaknya pilihan informasi di dunia maya digital mengakibatkan pemuda mudah sekali terjerumus ke dalam berbagai jebakan teknologi informasi yang bertujuan menjauhkan pemuda dari gaya hidup kristiani. Demikian beberapa dampak dari digitalisasi informasi.

\section{Globalisasi informasi}

Globalisasi Informasi adalah menyebarnya informasi positif maupun negatif yang sulit dibendung secara teknologi dan akan saling memengaruhi gaya hidup masyarakat dunia. Apa yang terjadi di negara atau daerah lain akan dengan mudah dilihat dalam hitungan detik oleh kita melalui media sosial di internet. Dengan mudahnya masuknya gaya hiduponline konsumtif, hedonis, tontonan pergaulan seks bebas, perjudian online, kawin cerai, penyebaran homoseksual, perselingkuhan online, film poligami, kekerasan pergaulan, materialisme, terorisme dan lain-lain menjadi tantangan iman Kristen saat ini.

2. Terjadi revolusi komunikasi dari face to face menuju image to image atau text to text.

Aplikasi media sosial telah memudahkan manusia untuk berkomunikasi jarak jauh dengan mudah, murah dan real time. Manusia tergoda untuk tidak perlu bertemu di dunia nyata asalkan tetap bisa berkomunikasi bahkan pacaran atau berkeluarga online di media sosial menjadi alternatif komunikasi di tengah zaman manusia yang bermobilitas tinggi. Kebutuhan komunikasi yang mendesak dan

\section{Youlflf | Mei 2015}


setiap saat di dunia maya digital semakin meningkat. Menjadi tantangan kekristenan di zaman komunikasi media sosial bahwa manusia semakin tidak biasa dan tidak mengenal bahasa tubuh lawan bicara, serta tidak mengerti perasaan/emosi lawan bicara ketika berkomunikasi dengan text to text atau image to image.

3. Dunia maya digital menjadi sarana beredarnya berita hoax dan penyesatan.

Setiap orang bisa memproduksi informasi dalam bentuk teks, gambar atau video dengan berbagai tujuan. Foto palsu, video bohong, informasi menyesatkan, gambar editan, facebook duplikasi dan website serupa tetapi tidak sama beredar luas di dunia maya. Sehingga pembaca sulit membedakan informasi mana yang benar atau salah, mana yang fakta atau opini di berbagai lautan informasi. Informasi benar dan bohong di era postmodern digital ini menjadi kabur atau tidak jelas, yang ada hanyalah mana berita yang populer dan tidak populer. Jawaban benar atau salah, fakta atau opini adalah terserah pembaca. Di tengah beragamnya menyebarnya informasi, menjadi tantangan pemuda Kristen untuk perlu mengecek validitas informasi.

4. Alat-alat pintar digital menjadi tempat pelarian kehidupan atau tempat mencari kebahagiaan semu.

Dunia maya digital telah menjadi tempat hiburan yang serba lengkap dari kebosanan, rutinitas, kesendirian, dan kejenuhan hidup. Generasi digital akan cenderung untuk menyendiri dengan gadget-nya daripada beraktivitas di dunia nyata. Berbagai game online, epornografi, video interaktif, media sosial, cyber space dan lain-lain menjadi barang candu bagi
Dunia maya digital telah menjadi tempat hiburan yang serba lengkap dari kebosanan, rutinitas, kesendirian, dan kejenuhan hidup. Generasi digital akan cenderung untuk menyendiri dengan gadgetnya daripada beraktivitas di dunia nyata.

generasi ini. Generasi digital terus dihantui oleh kecanduan digital dan tergoda meninggalkan tanggung jawabnya di dunia nyata bahkan meninggalkan Tuhan Yesus. Kecanduan digital ditandai dengan penggunaan sebagian besar waktunya di dunia maya digital daripada di dunia nyata, turunnya produktivitas hidup dalam pekerjaan atau belajar karena terus bermain dengan alat-alat digital. Di zaman pemakaian telepon pintar yang semakin meluas ini, banyak pemuda yang tidak bijaksana dalam menggunakan telepon pintar dan jatuh dalam dosa dengan segala fasilitas aplikasi yang tidak membangun di telepon pintar.

5. Kemajuan inovasi teknologi yang sedemikian cepat, membuat perubahan kehidupan juga terus berubahubah semakin cepat, instan, dan praktis.

Masyarakat akan berlombalomba untuk meraih sesuatu dengan sangat cepat, hasil akhir adalah segalanya. Pemuda tergoda bergaya hidup serba cepat dan instan, mulai secepatnya men- 
jawab pesan di media sosial, mencari jawaban instan di search engine, belajar instan, sukses dengan carainstan, bahkan mencari ibadah minggu pun yang serba cepat. Akibatnya pemuda cenderung hanya mengerti kulit, kurang memahami isi secara mendalam, kurang memahami filosofi, kurang menghargai proses, maunya hasil yang cepat terwujud, kurang mau berusaha, maunya yang praktis, tidak sabaran, kurang mau berjuang, dan tidak tahan menghadapi tantangan. Gaya hidup instan digital menghasilkan pemuda yang tidak siap menghadapi tantangan global.

6. Melalui inovasi teknologi manusia terus berusaha membuat benda-benda digital serba pintar.

Para pakar teknologi berusaha untuk memasukkan kecerdasan buatan di berbagai benda digital untuk menggantikan logika-logika pikiran manusia sendiri. Manusia akan terbantu berinteraksi dengan alat-alat digital serba pintar. Alat digital pintar pun akan semakin menggantikan peran manusia. Kehidupan manusia akan lebih praktis, lebih cepat, lebih murah, lebih terintegrasi dan lebih nyaman. Godaan manusia zaman digital serba pintar adalah manusia mengandalkan bahkan memberhalakan teknologi pintar. Inilah zaman di mana manusia akan tergoda lebih mudah memalingkan dirinya pada dan berinteraksi dengan alat digital serba pintar daripada berinteraksi dengan Allah. Manusia akan terlalu mudah meninggalkan bahkan melupakan Tuhan dan men-Tuhankan benda-benda digital pintar yang bisa diprogram sesuai dengan keinginan manusia.

\section{Peperangan Rohani Era Digital}

Teknologi internet telah mampu menjangkau seluruh dunia dan menjadi alat komunikasi yang cepat, efektif, tanpa birokrasi, murah dan real time. Internet menjadi alat andalan untuk mempublikasikan opini, melipatgandakan pengikut, memengaruhi masyarakat luas, dan menyebarkan pengajaran. Dunia internet telah dibanjiri secara besar-besaran dengan ePornografi, game online, perjudian online, situs anti Kristus, cyber bullying dan sebagainya guna menggiring pemuda pada kecanduan digital, kebutaan rohani, dan penyesatan.

Tantangan iman Kristen terbesar di era digital adalah manusia terlalu mudah mendapatkan informasi apapun, sehingga banyak manusia tergoda jatuh dalam dosa bahkan ketika dalam keadaan sendirian di kamar dengan mudah mengakses misalnya situs pornografi. Inilah zaman teknologi serba pintar di mana kemajuan teknologi semakin canggih sekaligus disertai kerusakan moral semakin meluas. Ini zaman teknologi super komputer yang semakin diragukannya kehadiran Allah yang hidup dan semakin diandalkannya program-program pintar untuk membantu aktivitas manusia.

Inilah saatnya peperangan rohani era digital yaitu medan pelayanan Kristen tidak hanya di dunia nyata tetapi telah meluas ke dunia maya digital. Jika gereja tidak menggunakan mesin-mesin pintar dan internet dalam penginjilannya, maka dunia maya digital akan terus dipenuhi informasi penyesatan tanpa ada yang mengimbanginya.

\section{Gaya Hidup Digital Kristiani}

Perkembangan kemajuan teknologi tidak bisa dibendung. Arus keterbukaan informasi sulit dibendung atau disaring dengan alat-alat teknologi. Kondisi dunia terus berubah-rubah sesuai dengan perubahan kemajuan ilmu pengetahuan dan 


\section{Jika gereja tidak menggunakan mesin- mesin pintar dan internet dalam penginjilannya, maka dunia maya digital akan terus dipenuhi informasi penyesatan tanpa ada yang mengimbanginya.}

teknologi, serta kondisi rohani manusia terus diperhadapkan dengan berbagai godaan yang semakin terbuka, transparan dan meluas di segala bidang melalui alatalat digital. Tantangan era digital dan kompetisi dunia semakin berat, juga ditambah dengan kerohanian manusia semakin melemah. Gaya hidup digital sulit dihindari, tetapi juga tetap perlu bersikap kristiani dalam menjalaninya.

1. Gaya Hidup Menerangi Dunia Digital Di masa akan datang, semua orang di dunia akan saling terhubungkan dengan teknologi komunikasi dan informasi. Tidak ada manusia yang terpencil yang tidak bisa dijangkau dengan teknologi informasi. Telepon pintar menjadi sarana "all in one", yaitu tersedianya sarana yang lengkap dari hiburan sampai belajar. Manusia akan mengalihkan perhatian dan waktu pada telepon pintar. Beberapa manusia terjebak menghabiskan waktunya berjam-jam untuk mengecek email, chatting, menonton video, menonton televisi, main game, kecanduan epornografi, mendengarkan musik, browsing, membaca ebook ata u koran, saat teduh, membaca $e$ Bible melalui gadget. Godaan iman
Kristen pun sudah tersebar luas di dunia digital melalui berbagai software dan aplikasinya. Seharusnya pelayanan Kristen pun mulai menggarami dan menerangi dunia digital.

Banyak orang yang tersesat di dunia digital, dan membutuhkan pemudapemuda Kristen yang peduli untuk memberitakan Injil di sini. Jika orang percaya tidak menggunakan teknologi informasi untuk memberitakan Injil, maka orang tidak percaya akan terus gencar menggunakan teknologi informasi untuk menjauhkan orang dari Yesus. Hal-hal sederhana yang bisa dilakukan dalam memberitakan Injil melalui dunia digital misalnya: rutin mengirimkan renungan pagi, menyebarkan gambar-gambar kristiani, mempublikasikan kegiatan kristiani, meng-upload video kotbah atau lagu rohani, menyebarkan artikel-artikel Kristen, penginjilan pribadi melalui whatsapp, bbm, facebook, youtube, instagram, serta media sosial lainnya. Ladang pelayanan dunia maya digital menjadi ladang pelayanan yang sangat strategis untuk menjangkau banyak orang dari jarak jauh, online 24 jam, tanpa birokrasi apapun, tanpa biaya perjalanan, dan tanpa visa masuk suatu negara untuk mencapai seluruh dunia.

\section{Gaya Hidup Kritis Alkitabiah}

Informasi yang tersebar di dunia digital adalah informasi yang dikirim oleh berbagai macam orang/organisasi dengan berbagai macam motivasi. Tidak semua yang tersedia di internet adalah benar adanya. Itulah sebabnya kita perlu mengkritisi secara kristiani terhadap informasi yang kita terima. Orang tidak beriman seringkali sangat gencar dan profesional menggunakan media sosial untuk menyesatkan atau menjauhkan orang dari 
Kaum muda perlu

membangun gaya hidup kritis alkitabiah yaitu suatu gaya hidup yang terus mengecek kebenaran informasi yang diterima di media sosial dengan kebenaran Firman Tuhan. Kaum muda ditantang untuk peka dan mampu membeda-bedakan informasi berdasarkan tuntunan Firman Tuhan.

Yesus. Penyesatan informasi tersebut biasanya dibungkus dengan epornografi, game online, animasi interakif atau film yang dibuat sangat profesional. Informasi yang masuk melalui media sosial bersifat menyebar, sulit disaring, sulit dibendung, sulit dihapus, mudah dicopy, bersifat terbuka, transparan, dan mudah sekali diakses sehingga seringkali menciptakan budaya baru yang bersifat global terbuka dan mengikis budaya lokal.

Dunia internet adalah dunia perpustakaan terlengkap dengan segala ide serta pengaruh negatif dan positifnya. Jika kita tidak hati-hati memasuki dunia digital yang tanpa batasan ini dengan segala tipu muslihatnya, maka kita akan mudah terjerumus ke dalam filsafat duniawi dan terjebak berbuat dosa oleh gambar atau animasi yang menggoda. Pemuda perlu membangun gaya hidup kritis alkitabiah yaitu suatu gaya hidup yang terus mengecek kebenaran informasi yang diterima di media sosial dengan kebenaran Firman Tuhan. Pemuda ditantang untuk peka dan mampu membeda-bedakan informasi berdasarkan tuntunan Firman Tuhan. Membangun wawasan kristiani melalui disiplin saat teduh, membaca buku rohani dan Alkitab, masuk dalam komunitas Kristen dan berdiskusi dengan para senior atau pembina, menyembah atau memuji Tuhan tiap waktu berguna untuk membentengi diri dari informasiinformasi yang membelokkan kita dari kebenaran Firman Tuhan.

3. Gaya Hidup Berkarya dengan Teknologi Informasi

Orang beriman tidak perlu menjauhi gadget, atau mempertentangkan telepon pintar dengan iman Kristen. Jika teknologi di tangan orang jahat, maka dengan teknologi orang jahat akan semakin mudah berbuat jahat. Jika teknologi di tangan orang baik, maka dengan teknologi orang baik akan semakin mudah berbuat baik. Jika teknologi di tangan orang yang cinta Tuhan Yesus, maka orang yang cinta Yesus akan mempergunakan teknologi sebagai sarana melayani dan berkarya bagi Tuhan.

Membiasakan hidup disiplin dengan menggunakan telepon pintar sebagai alat berkarya adalah juga menghindarkan kita dari kecanduan game online, epornografi, perjudian digital, dan lain sebagainya. Dengan gadget seharusnya kita bisa lebih banyak belajar di perpustakaan elektron ik terlengkap di berbagai universitas, menggunakan video pengantar untuk belajar berbagai hal. Atau kita bisa berkarya membuat publikasi digital, website, animasi interaktif, aplikasi telepon pintar untuk sarana pelayanan. Dunia pelayanan juga membutuhkan alat bantu

\section{Yoully}


telepon pintar atau komputer untuk menyebarkan bahan saat teduh, mempublikasikan video kotbah, atau membuat buku-buku rohani digital.

\section{Gaya Hidup Terintegrasi}

Dalam skala besar atau kecil perubahan dan kemajuan ilmu pengetahuan dan teknologi terus terjadi. Kita hidup di zaman yang berubah-rubah sesuai dengan perubahan teknologi dan pengaruhnya masyarakat global. Siapa yang tidak mengerti dinamika zaman dengan segala perubahan teknologinya, maka dia akan ditinggalkan oleh zaman dan hidup dengan tidak kontekstual di wilayah yang serba digital.

Orang Kristen ditantang untuk hidup tetap beriman pada Kristus di segala zaman, bahkan lebih dari itu orang Kristen seharusnya hadir sebagai imam untuk menerangi segala bidang kehidupan. Orang beriman perlu mempelajari teknologi dan ilmu pengetahuan yang bersifat netral dan membuat sistem-sistem yang positif alkitabiah sebagai sarana perkabaran dan pengajaran Injil. Kedalaman mempelajari teknologi seharusnya tetap diimbangi dengan kedalaman mempelajari Firman Tuhan. Kedalaman mempelajari Firman Tuhan sangat diperlukan untuk memberitakan Firman Tuhan secara bertanggung jawab melalui sarana bidang keahlian kita masing-masing.

Intelektual Kristen perlu hadir "mendarat" di segala bidang kehidupan dan segala perubahan zaman. Hidup terintegrasi artinya hidup yang tidak terpecah atau memisahkan diri dari perkembangan teknologi dan tetap menjadi orang yang mencintai Tuhan Yesus yang mempunyai spesialisasi di bidangnya masing-masing.
5. Gaya Hidup Integritas Nyata dan Maya Bagaimanapun juga dunia maya digital adalah dunia yang bisa di-copy, diedit, di-hack, dan dipalsukan. Sehebathebatnya berinteraksi dan bermain di dunia maya digital, tetaplah yang asli adalah dunia nyata. Telepon pintar adalah alat pendukung berkomunikasi di dunia maya digital, seharusnya tidak boleh menggantikan komunikasi di dunia nyata, apalagi dalam konteks bergereja, berkomunitas Kristen dan berkeluarga. Gereja sebaiknya tidak tergoda untuk membuat iChurch atau gereja maya digital. Gereja adalah persekutuan orang-orang Kristen di dunia nyata yang perlu memberikan kesaksian hidup asli nyata bertemu muka dengan muka secara berkala atau rutin tanpa edit digital.

Teknologi tidak dapat menggantikan kehidupan nyata. Gaya hidup digital kristiani adalah gaya hidup yang menggunakan alat-alat digital untuk membantu aktivitas sehari-hari bahkan bermisi kristiani, tetapi tetap tidak melupakan tanggung jawab kristiani di dunia nyata dan berkomunitas di dunia nyata, mengutamakan interaksi manusia dengan Allah, manusia dengan manusia daripada manusia dengan mesin-mesin pintar. Integritas Kristen adalah kita mempunyai keteladanan, kesucian, dan kesaksian hidup Kristiani yang sama di dunia nyata maupun di dunia maya online.

\section{Gaya Hidup Bijaksana Teknologi Infor- masi}

Mesin pintar, media sosial, dan internet bisa memberikan dampak negatif atau positif tergantung seberapa bijaksananya seseorang menggunakannya. Semakin kita bijaksana menggunakan mesin pintar, maka semakin kita bisa memanfaatkan mesin pintar untuk hal-hal positif. 
Kebijaksanaan kristiani mengajarkan bahwa kita tidak boleh mempunyai ketergantungan atau kecanduan pada mesin pintar dan apalagi menggantikan Tuhan Yesus dengan mesin pintar di dalam hidup kita. Teknologi adalah sekadar alat dan benda mati dan tidak punya moral, sehingga bukan untuk di-Tuhankan.

Penggunaan mesin pintar hendaklah tidak mengganggu waktu saat teduh atau mengabaikan relasi kita dengan Tuhan, jam produktif waktu kerja, waktu belajar, waktu berkeluarga, waktu bersosialisasi di komunitas dunia nyata dan waktu-waktu penting lainnya.
Teknologi media sosial adalah teknologi untuk membangun pertemanan dan persahabatan lebih baik, tetapi kita tetap perlu menjaga etika Kristen dalam bermedia sosial, misalnya: saran ataupun kritikan yang menyangkut hal pribadi sebaiknya dilakukan lewat jalur pribadi atau inbox, tetap menjaga kehormatan orang lain dalam bermedia sosial, janganlah mengirimkan pesan di media sosial ketika kita sedang marah, tidak mengirim kan pesan atau gambar/fotoyang bersifat menghina kepentingan atau kepercayaan orang lain, dan tidak mengirimkan gambar pornografi. 


\section{Daftar Pustaka}

Brock, Brian. Christian Ethics in a Technological Age. Grand Rapids, Michigan: Wm. B. Eerdmans Publishing, 2010.

Careaga, Andrew, E-vangelism: Sharing the Gospel in Cyberspace. Lafayette: Vital Issues Press, 1999.

Johnstone, Patrick and Jason Mandryk. Operation World. UK dan WEC International: Paternoster Lifestyle, 2001.

Kaye, E. M. The Christian Church in the Digital Age: Over 501 Digital Ministry Ideas for Pastors and Christian Leaders. United Kingdom: Christian Digital Ministries, 2014.

Monsma, Stephen V. Responsible Technology: A Christian Perspective. Grand Rapids, Michigan: Wm. B. Eerdmans Publishing, 1986.

Noor Al-Deen, Hana S. and John Allen Hendricks. Social Media: Usage and Impact. United Kingdom: Lexington Books, 2012.

Tapscott, Don. Grown up Digital: How the Net Generation is Changing Your World. New York: McGraw Hill Professional, 2008. 